\title{
Steamboats and pleasure travels: success and failure of the first Spanish initiatives in the mid-nineteenth century
}

\author{
Gaetano Cerchiello* \\ gaetano.cerchiello@ua.es \\ José Fernando Vera-Rebollo* \\ jf.vera@ua.es \\ * University Institute for Tourism Research (University of Alicante) \\ Campus San Vicente del Raspeig \\ 03690 Alicante (Spain)
}

\begin{abstract}
Steam technology revolutionised maritime transport during the nineteenth century. Together with the establishment of the first regular lines, steamers soon led to the commencement of pleasure navigation. The aim of this article is to analyse the impact and scope of this process in Spain, by means of a study of the first experiences in the mid-nineteenth century. In addition to a brief introduction and final conclusions, the paper is structured around four sections. The first contains an appraisal of the situation of passenger transport. Some information is then provided regarding the first cruise in 1854. Next, the essay highlights some of the features of short excursions that were very well received by the public, especially in the island of Majorca. Finally, attention is given to a very special type of travel, the main attraction of which lay in the opportunity to witness an event of a military nature.
\end{abstract}

Key words: history of cruise, passengers transport, steamers, Spain 


\section{Introduction}

Since the end of the twentieth century, cruise activity has undergone a process of considerable expansion. The cruise has become a new mass market product thanks largely to the North American market. In 2014, nearly 6,400,000 European passengers took a sea voyage for pleasure, representing a mean annual increase of over 9 per cent in the last decade. ${ }^{1}$ In tune with the growing importance of this phenomenon, a great deal of research has been published in recent years. Interest in cruising, moreover, is no longer centred solely on its economic aspects, but also covers other, no less important, facets (social, cultural, environmental, and so forth). This vast bibliographical contribution also includes texts that approach the topic from an historical perspective. In this respect, David M. Williams and John Armstrong deserve special mention for their studies on the 'impact of the early steamers'. ${ }^{2}$ One of their greatest additions has been to illustrate the existence of 'steamboat pleasure traffic' in the United Kingdom from the second decade of the nineteenth century, that is, 'a generation before the first railway excursions'. ${ }^{3}$ Their writings, therefore, assert the 'pioneering role of the steamboat in the development of popular tourism', which has traditionally and erroneously been attributed to the railway. As stated by John K. Walton, this pioneering line of research made an 'important contribution to the history of tourism', helping to clarify the historical context in which recreational sea travel developed in its two distinct forms: the long elite cruise and the short popular excursion. ${ }^{4}$ The two activities evolved in different eras. The former began to develop at the end of the century. The maritime excursions, on the other hand, were a direct and immediate result of the first steamers.

\footnotetext{
${ }^{1}$ CLIA Europe and IRN Research, Statistics and Markets 2014, http://www.irn-research.com, accessed May 5, 2015.

${ }^{2}$ See among others the following works of John Armstrong and Derek M. Williams: 'The steamboat and popular tourism', Journal of Transport History 26, no. 1 (2005): 61-77; 'Steam Shipping and the Beginnings of Overseas Tourism: British Travel to North-Western Europe', Journal of European Economic History 35, no. 1 (2006): 125-148; 'The Steamship as an Agent of Modernisation, 1812-1840', International Journal of Maritime History 19, no. 1 (2007): 145-160; 'One of the noblest inventions of the age: British steamboat numbers, diffusion, service and public reception, 1812-c.1823', Journal of Transport History 35, no. 1 (2014): 18-34. With regard to first long elite cruises see the works of Derek M. Williams: 'Market Pressures and Innovation: The Orient Steam Navigation Co. and the Development of Pleasure Cruising, 1888-1900', The Northern Mariner/Le Marin du Nord 10, no. 4 (2000): 1-12; 'The Extent of Transport Services Integration: SS Ceylon and the First 'Round the World' Cruise, 1881-1882', International Journal of Maritime History 15, no. 2 (2003): 135-146.

${ }^{3}$ Armstrong and Williams, 'The steamboat', 61.

${ }^{4}$ John K. Walton, 'Tourism and maritime history', International Journal of Maritime History 26, no. 1 (2014): 113.
} 
This article aims to follow in the same direction, engaging with a very different reality from that of Britain. It is well known that in Spain, in the mid-nineteenth century, the limited domestic demand for tourism was basically restricted to balneotherapy and sea-bathing. The latter was limited to the Eastern reaches of the Cantabrian coast (in seaside towns in the Basque Country and in Cantabria), more elitist in terms of the type of demand, and the coast of Cadiz. ${ }^{5}$ In the Mediterranean area, sea-bathing developed at the end of the century, and some locations (Alicante, among others) were more closely associated with popular forms of spending the summer. ${ }^{6}$ In any case, the seaside holiday model began to flourish in Spain after a delay of many decades not only with respect to England, but also in comparison with France, Belgium, Germany and Holland. ${ }^{7}$ Meanwhile, other forms of tourism, including cultural tourism, had yet to germinate at that time.

From the perspective of inbound visitors, the scene was not very different. In the midnineteenth century, Spain was still far away from international routes. 'There is no country in Europe so little known and yet so well worth visiting', as an Irish traveller wrote in $1864 .{ }^{8}$ Not for nothing, Spain appears for the first time in the catalogues of Thomas Cook in 1872, whilst Baedaker did not consider the Iberian Peninsula to be worthy of attention in its guides until $1898 .^{9}$ This 'marginalisation' was due, above all, to structural reasons. The tourism infrastructure offered 'minimum levels of comfort'. ${ }^{10}$ The evaluation by foreign travellers of the condition of Spanish accommodation was usually very negative. The first edition of the Guide Joanne, published in France in 1859, reported that hotels or fondas (inns) were 'not very numerous and in general

\footnotetext{
${ }^{5}$ Carlos Larriñaga, 'El turismo en la España del siglo XIX', Historia Contemporánea 25, no. 2 (2002): 169-178; John K. Walton and Janet Smith, 'The first century of beach tourism in Spain. San Sebastian and the Playas del Norte from the 1830s to the 1930s', in Tourism in Spain. Critical Issue, eds. M. Barke, J. Towner and M.T. Newton, (Wallingford, Cab International: 1996), 35-39; Luis Alonso, 'The value of the water: the origins and expansion of thermal tourism in Spain, 1750-2010', Journal of Tourism History 4, no. 1 (2012): 21-26; Alet Valero, 'El turismo de playa en España entre 1850 y 1950', in Actas del simposio hispano-francés: desarrollo regional y crisis del turismo en Andalucia (Almeria, Instituto de Estudios Almerienses-Casa de Velázquez: 1994), 301-305.

${ }^{6}$ José F. Vera, Turismo y urbanización en el litoral alicantino (Alicante, Inst. Juan Gil-Albert: 1987), 47-69.

${ }^{7}$ Walton and Smith, 'The first century', 36.

${ }^{8}$ The quote is from John Pemble, The Mediterranean passion. Victorians and Edwardians in the south, (Oxford: Oxford University, 1988), 48.

9 Joan C. Cirer-Costa, 'Spain's new coastal destinations. 1883-1936: The mainstay of the development of tourism before the Second World War', Annals of tourism research 45, no. 2 (2014): 20.

${ }^{10}$ Luis Lavaur, 'Albores del turismo moderno (1850-1870). (I)', Estudios Turísticos 51-52, no. 1 (1976), 38; Rafael Recio, 'Aproximación a una historia de los edificios hosteleros españoles durante los siglos XVIII y XIX', Boletín del Arte 13-14, no. 1 (1992-1993): 171-193.
} 
inferior in all respects to those found in the major European cities'. ${ }^{11}$ The accommodation on offer at the time was based mainly on traditional posadas. The complaints about these referred to all aspects of the stay: comfort, food, cleanliness, treatment, and so on. ${ }^{12}$ On his voyage from Paris to Cadiz in 1846, Alexandre Dumas warned that the posadas to be found in the two Castiles, La Mancha and Andalusia were simply 'atrocious'. ${ }^{13}$ The 'shortage of quality accommodation' was evident in most of the country, perhaps with some exceptions in Madrid, the Basque Country and Catalonia. At the end of the 1860s, the British consul in Mallorca still noted that if Balearic island 'had a large and well-organized hotel ... its attractions would be increased, and more visitors would lighten it with their countenance'. ${ }^{14}$ As for the quality of transport, the assessments were equally overwhelming. Until the middle of the nineteenth century, travelling to some regions of Spain could turn out to be an 'exasperating' experience. It is well known that the introduction of the railway took place after an extreme delay. The first train lines did not begin to function until the 1850s, with the exception of the $28 \mathrm{Km}$. stretch from Barcelona to Mataró inaugurated in autumn 1848. In the opinion of various authors, roads as such were 'inadequate' and 'insufficient'. ${ }^{15}$ All of this in the context of a country that, due to its geography, had few navigable stretches of river. ${ }^{16}$ It is estimated that in around 1850 the Spanish road network did not exceed 8,000 Km. in length, compared to approximately $45,000 \mathrm{Km}$. in France. More than one Spanish province was still unfamiliar with paved roads. ${ }^{17}$ The main reason for this situation was the bad state of the royal finances. The scarcity of economic resources was also apparent in maritime transport. It may be significant in this respect that the official Spanish correspondence with the colony of the Philippines travelled aboard English steamers. The 'treasury situation', as recognised by the government itself

\footnotetext{
${ }^{11}$ The quote is from Lavaur, 'Albores', 41.

${ }^{12}$ On this regard see the excellent research by Santos Madrazo, El sistema de transportes en España, 1750-1850. Vol. 2, (Madrid: Colegio de Ingenieros, 1984), 455-501.

${ }^{13}$ Alexandre Dumas, De Paris à Cadix. Impressions de voyage, (Paris: Bourin, 1989), 426.

${ }^{14}$ The quote is from Richard J. Buswell, Mallorca and Tourism: History, Economy and Environment (Bristol: Channel View Publications: 2011), 3.

15 Among them, Antonio Gómez, Ferrocarriles y cambio económico en España (1855-1913), (Madrid: Alianza, 1982), 20-26; Miguel Artola, Los ferrocarriles en España 1844-1943. El estado y los ferrocarriles (1), (Madrid: Banco de España, 1978), 13-15. Esperanza Frax and Santos Madrazo, 'El Transporte por carretera, siglos XVIII-XX', TST 1, no. 1 (2001): 31-40.

${ }^{16}$ David R. Ringrose, Los transportes y el estancamiento económico de España (1750-1850), (Madrid: Tecnos, 1972), 25-38.

${ }^{17}$ Frax and Madrazo, 'El Transporte', 35.
} 
in 1845 , precluded the establishment of a regular service with the Asian colony by means of vessels registered in Spain. For this reason, it was considered 'convenient' to take advantage of the stopovers made by the P\&O steamers in Gibraltar. ${ }^{18}$

In addition to structural obstacles, a certain 'perception of unsafeness' can be added, which was associated with the experience of travelling in Spain. ${ }^{19}$ In general, those who visited the country did so convinced that sooner or later they would be the victims of an assault by bandoleros or rateros (thieves), or even that they would be involved in some mutiny or uprising. ${ }^{20}$ 'The general opinion is that Spain is still one of the countries that one cannot visit without first having made a will,' noted the Guide Joanne with certain irony. ${ }^{21}$ Dumas himself admitted that he had travelled with the idea that the roads from Bayona to Madrid were 'infested' with wrongdoers. ${ }^{22}$ Exaggerated or not, these testimonies contributed enormously to reinforcing the 'unfavourable' image that Spain maintained until the end of the nineteenth century.

Despite all of this, this article will illustrate a certain similarity to what took place in the United Kingdom. In this sense, in Spain, too, where steam navigation was introduced and became generalised several decades later than in Britain, the new-vessels soon inspired the first pleasure trips. The study is mainly based on the written press. Working with this primary source, subjected to filtering and verification to ensure its validity as research data, is vital in order to reconstruct the historic background of modern cruising. ${ }^{23}$

\footnotetext{
18 Gaceta de Madrid, November 1, 1845. On this regard Gaetano Cerchiello, 'Turismo de eventos: los cruceros españoles en la inauguración del Canal de Suez de 1869', Cuadernos de Turismo 35, no. 1 (2015): 97-99.

${ }_{19}$ Madrazo, El sistema de transportes, 577-672.

${ }^{20}$ Jesús C. Ortiz de Urbina, 'Escritores franceses del siglo XIX, viajeros por España. Color local y enriquecimiento léxico', Thélème. Revista complutense de estudios franceses 4, no. 2 (1993): 61; Eugenia Afinoguénova and Eduardo Rodríguez Merchán, 'Picturesque violence: tourism, the film industry, and the heritagization of 'bandoleros' in Spain, 1905-1936', Journal of Tourism History 6, no. 1 (2014): 39-40.

${ }^{21}$ Lavaur, 'Albores', 40 (authors' translation).

${ }^{22}$ Dumas, De Paris à Cadix, 47-48.

${ }^{23}$ Similar methodology is found in the previously cited works of Armstrong and Williams. See also Frances Steel, 'Cruising New Zealand's west coast sounds: Fiord tourism in the Tasman world c. 1870-1910', Australian Historical Studies 44, no.1 (2013): 361-81.
} 


\section{Steamers and passenger traffic}

In mid-August 1848, the Majorcan press published a curious advertisement entitled 'Pleasure voyage from Palma to Algiers' (Figure 1). ${ }^{24}$ The announcement referred to the organisation of a sea trip to the North African city, departing on 3 September with the return trip to the island of Majorca scheduled for 8 September. The Compagnie du bateau à vapeur Languedoc, a small French shipping company that operated the liner service on the Sète-Palma-Algiers route, arranged the event. $^{25}$ The advertisement is most probably the first publicity for a maritime pleasure voyage in Spain.

Figure 1 Advertisement for a 'pleasure voyage' from Palma de Mallorca to Algiers (1848)

\section{VIAJE DE RECREO DE PALMA Á ARGEL.}

La empresa del vapor de hierro el Langüedoc de la fuerza de 300 caballos, propone al público mallorquin un viaje desde Palma á Argel, saliendo de este puerto el dia 3 de setiembre próximo à las seis de la tarde para llegar à $\Delta$ rgel el 4 por la mañana verificando la travesia en quince horas, debiendo salir de Argel para regresar á Palma el 7 del propio mes por la tarde y lleçar el 8 por la mañana.

The owners of the iron steamship the Langüedoc, of 300 horsepower, offer the Majorcan public a voyage from Palma to Algiers, sailing from this port on $3^{\text {rd }}$ September at 6 p.m. to reach Algiers on the morning of the $4^{\text {th }}$, completing the crossing in fifteen hours, and leaving Algiers to return to Palma on the $7^{\text {th }}$ day of the same month and arriving on the morning of the $8^{\text {th }}$.

Source: El Balear, 16 August 1848, 4 (translation by authors).

${ }^{24}$ El Balear, August 16, 1848; El Genio de la Libertad, August 16, 1848; Diario Constitucional de Palma de Mallorca de Mallorca, August 17, 1848.

${ }^{25}$ In the middle of the nineteenth century, regular traffic between Spain and Algeria was performed exclusively by French companies, which established intermediate stopovers at several Spanish ports. From the 1860s Spanish lines were gradually introduced, mainly attracted by the growing demand of Spanish emigration (temporary or permanent) to Algeria; on this regard see Juan B. Vilar, Los españoles en la Argelia francesa (1830-1914), (Murcia: CSIC, 1989), 55115. 
The project was an 'imitation' of another voyage that took place a few weeks previously on board the same steamship, when a group of passengers from Algiers arrived at the port of Palma for the 'sole purpose' of spending a few days 'at leisure' on the island of Majorca. ${ }^{26}$ In its second initiative, therefore, the company decided to reverse the route and address the 'Majorcan public' or, more precisely, its restricted wealthy class, the only people with sufficient time and money to grant them access to this new mode of travel. The fare of 30 pesetas per person (about $22 s$ ) represented a rather large sum of money, more so taking into account that the price established by the organisers only included the return passage, and did not cover the cost of meals. By way of comparison, 30 pts on the island of Majorca was equivalent to an annual subscription to the main local newspaper, the Diario Constitucional de Palma. ${ }^{27}$

The pleasure trip to Algiers did not ultimately take place. First, it was delayed due to a 'small' breakdown suffered by the boat. On 30 August, the newspaper reported that the French steamer was obliged to move to Toulon for necessary repairs, and that the departure would therefore take place on 12 September. ${ }^{28}$ Then, something else must have happened. After an exhaustive analysis of the maritime chronicles of port traffic in Palma de Mallorca, no operation appears for the French steamer on the scheduled days. Everything would seem to indicate that the company was unable to assemble the minimum number of one hundred participants, according to a clause included in the first advertisement for the voyage. ${ }^{29}$ Furthermore, it is easy to suppose that the three repeated breakdowns suffered by the Languedoc in the months prior to the planned departure did not facilitate the task of the organisers vis-à-vis their reduced clientele. In general, as is well known, the first steam ships experienced many problems, which only began to be reduced in the final decades of the nineteenth century, thanks to continued technological improvements. ${ }^{30}$

\footnotetext{
${ }^{26}$ La Esperanza, August 21, 1848.

${ }^{27}$ The exchange rate used in this essay is based on Pablo M. Aceña and María A. Pons, 'Sistema monetario y financiero', in Estadísticas Históricas de España, Siglos XIX y XX, eds. Albert. Carreras and Xavier Tafunell (Bilbao: Fundación BBVA, 2005), 703-4.

${ }^{28}$ Diario Constitucional de Palma de Mallorca, August 30, 1848.

${ }^{29}$ See also El Genio de la Libertad, August 29, 1848.

${ }^{30}$ For further comments on this matter see D. Deadrick, The Tentacles of Progress. Technology Transfer in the Age of Imperialism, 1850-1940 (Oxford: Oxford University, 1988), 25; José M. Valdaliso, 'La transición de la vela al vapor en
} 
In order to obtain a better understanding of the 1848 voyage to Algiers, and to grasp its significance, it is worth situating the event within the general context of maritime passenger travel. In the middle of the nineteenth century, passenger conveyance by sea was very limited in Spain, and merely formed a complement to cargo transport. This situation is reflected in the table below, which summarises the passenger traffic that disembarked in Majorca in 1848. That year, according to sea traffic-related news in the island's newspapers, the island port received 832 merchant vessels and a total of 4,290 passengers. These data point to an average of little more than 5 passengers per disembarkation.

Table 1 Passenger traffic disembarking in Palma de Mallorca in 1848 according to type of vessel*

\begin{tabular}{|c|c|c|c|c|}
\cline { 2 - 5 } \multicolumn{1}{c|}{} & Number of & Number of & Operations originating in & Passengers originating in \\
& operations & passengers & Barcelona & Barcelona \\
\hline SAILBOATS & $\mathbf{7 7 6}(93.3 \%)$ & $\mathbf{2 , 8 5 6}(66.6 \%)$ & $\mathbf{1 0 3}(74.6 \%)$ & $\mathbf{7 4 3}(43.7 \%)$ \\
\hline STEAMERS & $\mathbf{5 6}(6.7 \%)$ & $\mathbf{1 , 4 3 4}(33.4 \%)$ & $\mathbf{3 5}(25.4 \%)$ & $\mathbf{9 5 7}(56.3 \%)$ \\
\hline Total & $\mathbf{8 3 2}$ & $\mathbf{4 . 2 9 0}$ & $\mathbf{1 3 8}$ & $\mathbf{1 , 7 0 0}$ \\
\hline
\end{tabular}

* In parenthesis, the respective percentage of the total. Fishing boats are not included.

Source: Diario Constitucional de Palma de Mallorca and El Genio de la Libertad, daily editions of the year 1848.

The above information allows us to obtain a more nuanced reading of the situation. First and foremost, traditional sailboats in the middle of the century were absolutely dominant, reaching more than $93 \%$ of total port traffic. By contrast, the presence of modern steamers at the ferry terminal of Palma was nominal, with just 56 arrivals recorded during the whole year (6.7\%). This data is not surprising since in 1848 the Spanish merchant navy had only 24 steamers, compared with more than 4,600 sailboats. ${ }^{31}$ What is more significant, however, is that the new-technology ships already

la flota mercante española: cambio técnico y estrategia empresarial', Revista de Historia Económica 10, no 1 (1992): 64.

${ }^{31}$ Anuario de estadística de España 1858 (Madrid: Junta General de Estadística, 1859), 638-9. 
accounted for around a third of all passenger traffic, despite the scarceness of their operations. Moreover, taking into account that a considerable number of passengers arriving in Palma came from the nearby islands of Ibiza and Menorca, routes on which only sailboats operated that year, the data relative to traffic originating in Barcelona is more revealing. On this route, the main connection between Majorca and the Spanish mainland, steamers already accounted for a considerable proportion of passenger transport in the middle of the century.

The new steam technology brought a whole series of advantages to maritime navigation. ${ }^{32}$ In the first place, it assured greater speed and with it the shortening of distances. For example, the steamer Languedoc covered the Algiers-Palma route (around 180 miles) in approximately 15 hours, whereas the time taken by a sailing ship varied considerably as a result of wind and sea conditions. Even with favourable seas and clear skies the time taken by a wind-powered vessel to cover the distance was never less than two days. The maritime chronicles of that year illustrate that the crossing of a merchant sailboat between Algiers and Palma could even take longer than a week. Second, the propulsion of the engines guaranteed greater regularity in the crossings, together with greater manoeuvrability, allowing meteorological whims to be kept in check. With sailboats, as an anonymous Spanish reporter of the era reflected, nobody 'can ever calculate precisely whether it will be long or short, even when the point of arrival and the point of departure are very close'. ${ }^{33}$ Steam made possible to establish the first regular lines, first along coastal routes and then traversing whole oceans. Steam ships took over the official services for the carrying of mail, or to be more precise, public subsidies introduced for this purpose. Rather than simply extra revenue, these subsidies offset the high operating costs caused mainly by the vast quantity of coal necessary to move the ship. ${ }^{34}$ All of this helps explain the considerable difference in the price of the passage according to the type of vessel. For example, for a return trip between Palma and Barcelona in 1848 , the fares per person on a steamboat were 15 pts $(11 s)$ on deck and 35 pts $(26 s)$ in saloon.

\footnotetext{
${ }^{32}$ Alain Servantie, 'Development of steamship travelling in Mediterranean (1833-1860)' in Seapower, Technology and Trade, eds. Dejanirah Couto, Feza Gunergun and María P. Pedani, (Istambul: Piri Reis University, 2014), 504; Armstrong and Williams, 'The steamboat', 63.

33 'Navegación de vapor trasatlántica', Diario de Barcelona, September 6, 1855 (authors' translation).

${ }^{34}$ Valdaliso, 'La transición', 63-4.
} 
Travelling by sailboat was much less expensive; it usually cost 5 and $10 \mathrm{pts}$ respectively $(3 s .7 d$ and $7 s .2 d) .{ }^{35}$

Although steam engines eventually made it possible to construct larger vessels with increased transport capacity, screw propellers and more efficient engines took time to evolve. At first, the presence of boilers, machinery and coal stores greatly reduced the cargo capacity of the first steamers, making it essential to promote the new mode of transport among passengers. They 'had the double advantage of being willing to pay a good price and not requiring hold space' ${ }^{36}$ Until well into the second half of the nineteenth century, steamers were mainly used for the movement of people, and only later became fully involved in cargo transport.

Finally, the appearance of steam led to drastic transformations not only in navigation, but also in the structure and organisation of the companies involved. The need for capital to finance the creation and development of this activity led to legal changes. The new Spanish shipping entities were incorporated as trading companies, with the primary aim of securing resources. General and limited partnerships were among the dominant models in the first decades of steam, whilst in the last quarter of the century public limited companies were more prominent. ${ }^{37}$ This process allowed the mobilisation of a larger volume of capital to finance the high cost of steam navigation. Furthermore, it provided the entry of businessmen with new entrepreneurial visions, beyond the strictly commercial. The majority of traditional Spanish sailboat operators were, on the contrary, merchants who had become ship owners. As several authors have pointed out, many of them 'travelled on board their ships, commanding them as captains'. 38

The possibility of pleasure travel to Algiers, like the other initiatives described below, should be positioned within the context of the evolution and expansion of sea-going passenger traffic as a result of the application of the steam engine to the propulsion of boats. As an anonymous reporter

\footnotetext{
${ }^{35}$ The estimated exchange rate is based on Aceña and Pons, 'Sistema monetario'.

${ }^{36}$ Armstrong and Williams, 'The steamboat', 63.

${ }^{37}$ Martín Rodrigo, 'Navieras y navieros catalanes en los primeros tiempos del vapor 1830-1870', TST 13, no. 2 (2007): 85-87; José M. Valdaliso, 'Las navieras españolas en el espejo británico (c. 1860 - c. 1914): la transferencia de capitales, sistemas de gestión y modelos de financiación en una industria internacionalizada', TST 13, no. 2 (2007): 99.

38 Among them, José R. García, 'La marina mercante asturiana, 1849-1900', TST 13, no. 2 (2007): 155; Rodrigo, 'Navieras', 86.
} 
for the Diario de Barcelona pointed out in 1855, 'although the Spanish do not have the same fondness for travelling as the English ... all in all [their] fondness is increasing, and it would increase more visibly if communications were fast and comfortable. ${ }^{39}$ In short, thanks to its undoubted advantages, the new means of transport led to the creation of a new product, offering the first steam companies the opportunity to boost limited Spanish passenger traffic.

\section{The first Spanish cruise: the steamer Ebro to the Balearic Islands}

The ill-fated excursion of the steamer Languedoc did not end sea-going pleasure trips. Strong growth took place in the emerging steam navigation sector in Barcelona, with registration of 18 of the 44 new steamers registered in Spain in the decade between 1848 and 1858 taking place in that city. ${ }^{40}$ The incorporation of new ship owners reflects the local business community's interest in the new means of transport. One of the most evident examples was the limited partnership Pablo María Tintoré. ${ }^{41}$ Created for the purpose of establishing a transport service between Spain and England, the new firm incorporated in November 1852. The majority of the 21 founding shareholders were businessmen who lived in the Catalonian capital. ${ }^{42}$ Its activity began formally on 1 March 1854 , when its first steamer, the Ebro, inaugurated the Liverpool-Barcelona line. After several scheduled calls at other Spanish ports, the boat finally reached Barcelona on 13 March $1854 .{ }^{43}$ As for its technical characteristics, the vessel had a length of 61 metres, with an iron hull and a propeller, one of the first with this system of propulsion to be registered in the Catalonian capital. ${ }^{44}$

After the arrival at Barcelona, the ship was the subject of a public guided tour, in which members of the local press participated. ${ }^{45}$ Apart from its promotional purpose, and the subsequent publicity in the news media, such viewings of new watercraft of this type were very frequent. This

\footnotetext{
39 'Navegación de vapor trasatlántica' (authors' translation).

${ }^{40}$ Anuario 1858.

${ }^{41}$ On the first Catalan steamship lines, Rodrigo, 'Navieras', 63-92.

42 Ibid.

${ }^{43}$ Diario de la Tarde, March 14, 1854.

${ }^{44}$ Lista oficial de los buques de guerra y mercantes de la marina española de 1871 (Madrid: Ministerio de Marina, 1871).

45 'Vapor Ebro', Diario de la Tarde, March 17, 1854.
} 
fact is a reflection of the attraction and the popular impact of the first steamers. In general, the launch of a new steamboat represented a real event. Indeed, according to contemporary newspaper reports, people would arrive in large numbers to see the modern ships for themselves. It should be remembered that almost all the steamers registered in Spain during this period came from abroad, built mainly in British shipyards. Whilst the majority of the merchant sailing ships registered in Spain were built by Spanish companies, throughout the nineteenth century the technical lag and the lack of qualified labour (among other reasons) hindered the creation of a modern shipbuilding industry that was able to compete with foreign shipyards. Significantly, in around 1883 , out of a total of 407 steamers registered in Spain, just 22 were of domestic construction, whilst 341 came from the United Kingdom. ${ }^{46}$

Three months after the opening of the Liverpool-Barcelona line, the shipping company Tintoré promoted a voyage 'purely for pleasure' to the Balearic Islands. ${ }^{47}$ An advertisement was published repeatedly in the main local newspapers, informing of a tour to be made on board the Ebro around the islands of Menorca and Majorca at the end of June 1854. As was underlined by the newspaper El Áncora, this was the 'most propitious' occasion to visit the 'enchanting' islands, especially for those who did not have 'personal obligations'. ${ }^{48}$ In the morning edition of 21 June 1854 , the Diario de Barcelona informed of the following:

\section{PLEASURE VOYAGE TO THE BALEARIC ISLANDS}

The fine Spanish steamer Ebro will depart on Wednesday $28^{\text {th }}$ [June] at 6 o'clock in the afternoon for Mahón and Palma. It will depart from Mahón at sunrise on Saturday to reach Palma in the afternoon. It will remain in Palma until Sunday evening, arriving in Barcelona on Monday morning. It admits passengers only. ${ }^{49}$

\footnotetext{
${ }^{46}$ The data, which refers to ships of more than 50 gross tonnage, is available in Esperanza Frax and María J. Matilla, 'Transporte y comercio marítimo en los siglos XVIII y XIX' in Puertos españoles en la historia (Madrid: Ministerio de Obras Públicas, Transportes y Medio Ambiente 1994), 98.

${ }^{47}$ The first advertisement in the Diario de Barcelona, June 11, 1854.

48 'Viaje de recreo', El Áncora, June 23, 1854.

${ }^{49}$ Diario de Barcelona, June 21, 1854 (authors' translation).
} 
According to the schedule, the voyage of the Ebro lasted for 7 days, including two long stopovers in Menorca and Majorca. A total of 75 passengers travelled on board the ship from Barcelona, and they were accommodated in saloons fore and aft, as well as on deck. Those without a cabin decided to spend the night at inns in Mahón and Palma, but the 'limited number' of facilities in Palma made it necessary for some of the passengers to find lodging in various private homes, highlighting the deep-rooted shortage of accommodation on the island of Majorca. ${ }^{50}$ Despite this trouble, Ebro passengers were 'very satisfied' with the experience, emphasising the 'natural beauty' of the two islands. Finally, at 11 o'clock in the morning on 3 July 1854, the steamer returned to the port of Barcelona. $^{51}$

\section{Recreational day trips}

From the mid-nineteenth century, pleasure maritime excursions also began in Spain. The first recreational day trips were generally planned around an organised visit to a nearby location of interest for tourism, or to witness some important event. From the point of view of the organisers, this practice offered many advantages compared to longer voyages. Apart from the objective difficulties in organising and accomplishing long cruises, excursions represented a good way of making the business profitable. First, any risk of alteration to the regular activity of the vessel was eliminated, since it was easier to find a gap in its schedule. This was possible even when the trip was postponed owing to adverse weather conditions, mechanical problems, or other causes beyond the ship owner's control. In other words, they did not involve any need to modify the operational calendar of the line. Moreover, such excursions could take place on Sundays or other public holidays, and even during times when the boat was at its busiest, such as in summer. All of this guaranteed greater attendance by the public. Furthermore, as a consequence of the short duration of the crossing and the non-inclusion of nights on board, it was possible to transport a larger number of customers, distributing the passengers on deck or in other areas of the boat. It should not be

${ }^{50}$ El Balear, July 2, 1854.

${ }^{51}$ Diario de Barcelona, July 4, 1854, July 5, 1854; El Genio de la Libertad, July 10, 1854. 
forgotten, in fact, that the first steamers dedicated to short- and mid-distance traffic usually had a limited number of cabins, as well as being small and generally uncomfortable. ${ }^{52}$ Lázaro Bardón, one of the Spanish guests at the inauguration of the Suez Canal in 1869, offers us valuable testimony regarding this detail. In the priceless diary of his voyage, where he narrates the crossing from Marseilles to Port Said on board the steamer Guienne of the Compagnie des Messageries Impériales, the 'unfortunate' passenger describes with subtle irony the characteristics of his fourman cabin in the first class:

Imagine a closed space, with a capacity of two metres in length, two metres in width and another two in height (...); four immobile beds, one above the other, like burial niches in a cemetery (...); a chest of drawers nailed to the floor, with three drawers and washbasins fixed on top, and you will have precisely the remaining space in which the four half-alive bodies must move around (...). And all the bow cabins were alike. Thus, when it was time to go to bed and to arise, grotesque scenes abounded since the rear ends of some frequently coincided with the olfactory organs of others. ${ }^{53}$

Therefore, from this perspective too, the first steamers were far more appropriate for pleasure trips of short duration. The possibility of addressing a wider and more diverse public represented another of the strong points of this type of trip. On the one hand, the reduction in expenses of all kinds (coal, port taxes, etc.) resulted in a more affordable fare price. On the other, the shortness of the event also opened the door to those who were not altogether free from personal obligations, favouring proximity with other members of the upper echelons of society. Based on these premises, therefore, it is not surprising that the market response to these activities was very relevant in numerical terms, as is clear below.

From the geographical point of view, sea trips first began to proliferate in the Mediterranean area, and subsequently in the North of Spain, where steam navigation extended after a certain

\footnotetext{
${ }^{52}$ On this matter see Lynne Withey, Grand Tours and Cook's Tours (New York: William Morrow, 1997), 173-4.

${ }^{53}$ Lázaro Bardón, Viaje a Egipto con motivo de la apertura del canal de Suez y excursión al mediodía de Italia, (Madrid: 1870), 8 (authors' translation).
} 
delay. ${ }^{54}$ At the end of 1858, in fact, the northern provinces of Spain (from Galicia to Basque Country) counted a total of 13 steamers, less than $16 \%$ of the new-technology vessels registered in Spain. ${ }^{55}$ In chronological order, the first and fragmented pieces of news regarding the organisation of a sea trip originated in Barcelona, and refer to two initiatives programmed for Saturday and Sunday, the 8th -9 th of September 1855. The destinations of the trips were the nearby towns of Sitges and Villanueva, respectively. In both cases, the passengers would travel aboard the Villa de Sueca, a small, recently built steamer that subsequently operated on coastal routes. ${ }^{56}$

More evidence is available of another project that was undertaken a few months later in the Balearic archipelago. The Empresa Mallorquina de Vapores, a new shipping company that was incorporated in Palma in 1855, promoted a short 'pleasure trip' to the nearby island of Cabrera planned for Sunday 17 February $1856 .{ }^{57}$ Provided that the weather was 'calm', the Rey Don Jaime I would be boarded at eight o'clock in the morning, whilst the return trip would be completed 'at nightfall' on the same day. ${ }^{58}$ Built in London shipyards, the steamer had recently docked for the first time in the port of Palma, drawing the 'admiration' of the 'numerous' members of the public that had arrived to witness its entry. This event was widely reported in the local press, which emphasised the usual enthusiasm that would accompany the first appearance of steam ships on the island of Majorca. ${ }^{59}$ The incorporation of the new vessel in the fleet of the Balearic merchant navy was expected not only to guarantee greater 'punctuality' in communication with the peninsula, but to satisfy the 'fondness for travel' of the Majorcan people. Moreover, the daily newspaper El Balear emphasised the 'comfortable and spacious' saloons, which it considered 'necessary' in order to render 'the discomforts' suffered by the Majorcans during their crossings 'less perceptible'. ${ }^{60}$

Owing to inclement weather, the 1856 trip to Cabrera was postponed until the following Sunday, 24 February. It is worth drawing attention to two related facts. The first is the company's

\footnotetext{
${ }^{54}$ Valdaliso, 'La transición', 66.

${ }^{55}$ Anuario estadístico de España correspondiente a 1859 y 1860 (Madrid: Junta General de Estadística, 1860).

${ }^{56}$ Diario de Barcelona, September 5, 1855.

${ }^{57}$ El Genio de la Libertad, February 12, 1856.

58 Ibid.

${ }^{59}$ Joan Pou, La Marina en las Baleares: síntesis histórica (Palma de Mallorca: Caja de Ahorros, 1977), 115; El Balear, February 5, 1856.

${ }^{60}$ Ibid.
} 
initiative to include an orchestra on board the boat. The musical performance, with an emphasis on patriotic hymns, 'entertained' the passengers and made the trip 'more agreeable'. In a festive atmosphere, the passengers returned to the port of Palma at nightfall, where many local residents were able to witness their arrival. As the ship approached the port the crowd increased 'extraordinarily'. ${ }^{61}$ The second is the extensive participation of the public, which included the unusual presence of 'a great many' women. Ultimately, 'around' 400 travellers wished to discover the 'unsurpassable conditions' of the ship and 'enjoy' a day of leisure. ${ }^{62}$ From any point of view, this is an exceptional figure for sea traffic at that time. The response of the public takes on greater importance if we take into account that the first day trips excluded a priori the great majority of the population. In fact, the price per person of the trip to Cabrera was 5 pts (a little over $4 s$ ): a not inconsiderable sum for the people of Majorca around 1856, equivalent for example to the value of a, 1175 page Spanish language dictionary.

From the beginning of its activity, the Empresa Mallorquina de Vapores showed a great interest in pleasure sailing. As well as the Sunday excursions, the company tried to arrange expeditions of longer duration, including trips abroad. A few days after the acquisition of its first steamer, the Balearic Islands press included 'rumours' that were circulating about a long recreational voyage, provided that a 'sufficient' number of passengers could be found. The trip on this occasion was an expedition to Italy, with a long stopover in Civitavecchia, in order to attend the 'Easter week functions in the capital of the Christian world' ${ }^{63}$ And just under two months later, on 14 April 1856, the company officially announced its intention to undertake a pleasure trip of 7 days to Algeria, departure being subject once again to the requisite of a minimum number of bookings. ${ }^{64}$ In both cases, however, the projects did not come to fruition. The lack of clientele finally obliged the company to modify its plans and renew the regular service between Palma and Barcelona.

\footnotetext{
${ }^{61}$ El Genio de la Libertad, February 25, 1856.

${ }^{62}$ Ibid.

${ }^{63}$ El Palmesano, February 20, 1856; El Genio de la Libertad, February 21, 1856.

${ }^{64}$ El Balear, April 14, 1856.
} 
In this respect, the difficulties inherent in arranging cruises of several days were confirmed, showing at the same time a clear difference with the trips with no overnight stay. The latter, in fact, continued to make a strong impact among the local population. A 'multitude' of people, for example, flocked to the port of Palma de Mallorca on 18 July 1860. On this occasion, their purpose was to participate in the 'recreational and instructive' voyage to the neighbouring town of Andraitx, in the south-west of the island, and to be able to 'observe from there the total eclipse of the sun' (figure 2). In exchange for 5 pts per passenger (a little over $4 s$ ), the company made available to its clientele the Rey Don Jaime II, a new steamer it acquired at the beginning of 1858, after being awarded the mail service between the Iberian Peninsula and the Balearic Islands. ${ }^{65}$

Figure 2 Announcement of the 'recreational and instructive voyage' from Palma de Mallorca to Andratx on 18 July 1860

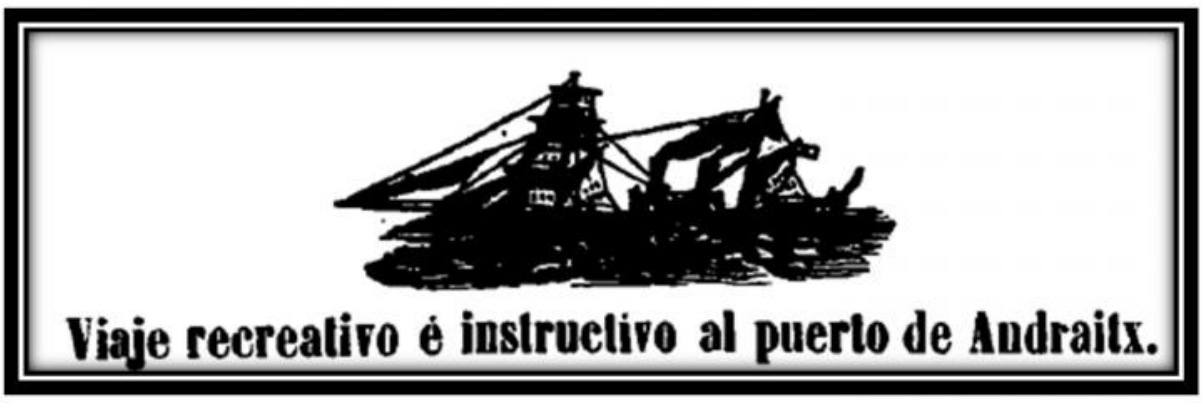

Source: El Isleño, July 16, 1860

The company undertook another project in 1862, for the purpose of visiting the caves of Artá, in the north-east of the island of Majorca. Local sources state that two steamers travelled towards this 'wonder of nature' on Sunday 27 July $1862 .{ }^{66}$ The first, the Rey Don Jaime II, left first thing in the morning with around 400 people on board. ${ }^{67}$ Prior to the departure, and for the 'greater convenience' of its clientele, the shipping company arranged for a short mass to be held in the

\footnotetext{
${ }^{65}$ El Isleño, July 19, 1860.

${ }^{66}$ See El Isleño, July 24, 1862 and the manuscript Viaje de recreo a las cuevas de Artá en Julio de 1862, Biblioteca Pública del Estado de Mahón, fondo MSS 96.

${ }^{67}$ El Isleño, July 29, 1862. More information in Gaetano Cerchiello, 'Los albores del crucerismo en la España del siglo XIX (1848-1865)', TST 20, no. 1 (2011): 74-5.
} 
nearby Palma Cathedral. ${ }^{68}$ The second expedition set out from the port of Mahón (Menorca). A total of 81 passengers travelled on board the Menorca, a small propeller-driven steamer belonging to the Sociedad del Vapor Mahonés. ${ }^{69}$ The meeting between the two ships took place near to Cala Ratjada, to the north of the caves of Artá, where locals turned out 'en masse' to receive the 'noisy' delegations. At nightfall, the Rey Don Jaime II returned to the port of Palma amid great expectation. Flares and fireworks lit up the quay, 'until the last tripper had disembarked' ${ }^{70}$

The 'satisfactory success' of the trip to Artá of 1862 encouraged Empresa Mallorquina de Vapores to repeat the initiative the following summer. As the formula worked, and people turned out in large numbers, organisers believed it appropriate to maintain the same script with regard to the destination (the caves of Artá), retail price (10 pts) and departure time (5 a.m.). Furthermore, the company considered it right to repeat the holding of a mass before leaving port, and to host a band of musicians on board to make the trip 'jolly' and 'lively'. ${ }^{71}$ A small novelty is worth mentioning in relation to the trip on 9 August 1863: the serving of food on board, in addition to the inclusion of the traditional 'abundantly stocked' galley. For increased customer satisfaction, passengers were offered the possibility of being served on board with 'all specialities', being able to order in advance the dishes they would like during the crossing. Around 300 people participated in this new day of leisure, which took place on the second Sunday of August in $1863 .^{72}$

To conclude this section, a mention should be given to the first initiatives that took place in the North of Spain in the 1860s, mainly in the city of Bilbao. The first projects were undertaken with the aim of facilitating attendance at specific events held in coastal towns, mainly those that were beginning to emerge as 'sea-bathing resorts'. ${ }^{73}$ Thus, for example, an excursion was arranged on the occasion of a 'great' pelota a blé match which was held in Santander on 5 April 1863. In order to attend the event, the owners of the steamers Vizcaíno-Montañés and Pelayo offered a 'pleasure

\footnotetext{
${ }^{68}$ Ibid.

${ }^{69}$ Diario de Menorca, July 29, 1862.

${ }^{70}$ Viaje de recreo, 3.

${ }^{71}$ El Correo de Mallorca, August 6, 1863.

${ }^{72}$ Ramón Sampol, Vapores de las islas Baleares (Palma de Mallorca: Miquel Font, 1988), 32.

${ }^{73}$ A detailed list of these resorts is found in Walton and Smith, 'The first century', 38.
} 
voyage' from the port of Bilbao, departing at half past four in the morning. The return voyage departed the following day at eleven o'clock at night. ${ }^{74}$ As a result, according to the report, the passengers could not only attend the match, but subsequently take part in a country dance and go to the theatre. $^{75}$

Continuing with the same modus operandi, another excursion took place in August of the same year on the occasion of the fiestas of Lequeitio, on the east coast of Biscay. This time it was the Empresa de los vapores Unión y Comercio that took the initiative. The purpose of the trip was to take passengers to 'unmissable' bull-fighting events and other diversions that formed part of the festivities in the Biscay town. ${ }^{76}$ The Comercio reached Lequeitio at around one o'clock in the afternoon on 9 August 1863, with 'more than' two hundred trippers on board, who were met with music, flares and 'other signs' of hospitality. ${ }^{77}$

The third and last example of this new phenomenon took place in August 1865. The Unión steamer company organised a 'pleasure voyage' from Bilbao to Zarauz, another emerging seaside resort on the Biscay coast. ${ }^{78}$ The project was organised to coincide with a short summer stay in the small Gipuzkoa town by the Spanish royal family. ${ }^{79}$ Sadly, according to the report, the trip on Sunday 13 August must have been anything but pleasurable. Dreadful weather conditions and heavy seas led to significant alterations to the schedule. Even at that, only a 'small number' of the passengers who had joined the initiative dared to board the steamer, together with some members of a band of musicians who tried to entertain them. Furthermore, that same night, all the festivities that had been organised in Zarauz were suspended, after news was received from Madrid of the death of Francisco de Paula of Bourbon. ${ }^{80}$

\footnotetext{
${ }^{74}$ The advertisement in Euscalduna, April 2, 1863.

${ }^{75}$ A brief account of the journey is available in Euscalduna, April 8, 1863.

${ }^{76}$ The advertisement in Euscalduna, August 7, 1863. See also La Iberia, August 7, 1863.

${ }^{77}$ Euscalduna, 13 August 1863.

${ }^{78}$ The advertisement in Euscalduna, 12 August 1865.

${ }^{79}$ On the Spanish royal family's stay in Zarauz, see a short reference in Larriñaga, 'El turismo', 176.

${ }^{80}$ Euscalduna, August 15, 1865. Son of Charles IV, Francisco de Paula (Duke of Cadiz) was the father in law of the Queen Isabel II.
} 


\section{Military cruises}

Although Spanish cruising took its first tentative steps in Barcelona and Majorca, the new mode of recreation began to make a timid appearance in other regions of Spain as well. Far from being a generalised phenomenon, simple, scattered attempts were made which, except in the case of day trips, were largely unsuccessful owing to lack of clientele. In view of this scenario, and with the aim of encouraging greater interest among the well-off, some steam companies tried to promote long voyages that coincided with military events. One of these was incorporated in Bilbao in the summer of 1865 . The Unión steamship company set up an 8-day 'recreational trip' to Cherbourg. The goal of the initiative, as specified in the announcement, was to attend a joint meeting of various naval war squadrons held in the French city in mid-August of that year. To recruit the minimum 100 passengers, the Spanish press emphasised that the 'extraordinary festival' would attract 'all the elegant and well-educated people of Europe'. ${ }^{81}$ This project is partly evocative of a type of voyage that started to become popular in the United Kingdom in the first half of the nineteenth century. The launch of a war ship often attracted the interest of British steam companies for the purpose of organising recreational trips. ${ }^{82}$ In September 1825, for example, the Medina steamer ventured to Portsmouth to see the launching of the first-rate 104 gun warship HMS Princess Charlotte. Two steamers even left from Southampton to Portsmouth in May 1839 to see the launch of the first-rate 110 gun HMS Queen. ${ }^{83}$

Included in this particular type of pleasure travel, we find another initiative that was planned in Malaga at the beginning of September 1859 to take place on board El Catalán, a steamer that had recently commenced liner service between Valencia and Barcelona. ${ }^{84}$ The destinations of the expedition would have been the military camp of Algeciras and the town of Ceuta, which had for several days been in the spotlight of Spanish public opinion after a series of border incidents with

\footnotetext{
${ }^{81}$ Ibid.

${ }^{82}$ Armstrong and Williams, 'The steamboat', 69.

${ }^{83}$ Ibid.

${ }^{84}$ La Discusión, September 18, 1859.
} 
Morocco. Tense relations between the two nations, which led to the commencement of hostilities the following October (Hispano-Moroccan War), put an end to any hopes of organising this trip.

In relationship to this military event, during which many Spanish merchant vessels were used for the transportation of troops or other logistic operations, the scene was set for a cruise in February 1860 to Tetouan, a city that had recently been conquered by the Spanish army. ${ }^{85}$ As usual, news filtered out regarding a very generic project; it seemed no more important than any other journalistic rumour regarding the 'glorious' African campaign. ${ }^{86}$ However, on 19 February 1860, the Madrid newspaper El Clamor Público published in capital letters the official announcement of the organisation of the voyage, 'on the occasion of the taking' of the Moroccan city (figure 3).

Figure 3 Announcement of 'large pleasure voyage' from Madrid to Tetouan (1860)

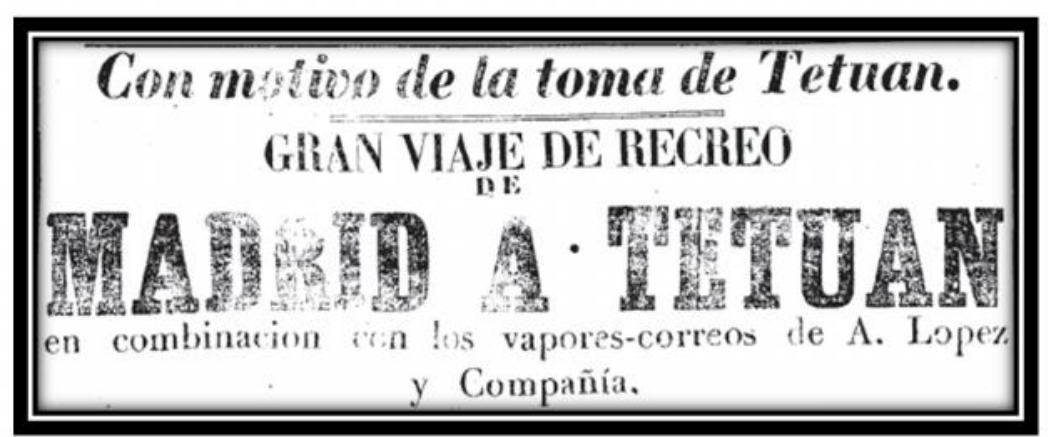

Source: El Clamor Público, February 19, 1860

The conquest of the city and the subsequent nationalist exaltation represented a wonderful opportunity to organise 'great' pleasure travel, and to carry clientele anxious to see the results of the 'Spanish feat'. The itinerary included important variations compared to the recreational sea voyages organised to date. The announcement read as follows:

OUTBOUND. Departure from Madrid, by special train, on Thursday $23^{\text {rd }}$ February at half past 5 in the afternoon. Arrival in Alicante on Friday at half past 6 in the morning. Departure on board the steamer on the same day at 8 o'clock sharp in the morning. Arrival in the bay of Tetouan on Saturday at 1 o'clock in the afternoon.

\footnotetext{
${ }^{85}$ The entry of Spanish troops into Tetouan took place on 6 February 1860. In accordance with the peace treaty of WadRas on the 26 April 1860, the town came under the direct control of the Spanish military authority.

${ }^{86}$ La Iberia, February 12, 1863.
} 
The travellers will stay in Tetouan from 1 o'clock on Saturday afternoon until Monday at 11 o'clock in the morning [...].

RETURN. Departure from Tetouan on $27^{\text {th }}$ February at 11 o'clock in the morning. Arrival in Alicante on Tuesday at 3 o'clock in the afternoon. Departure by special train at half past 7 in the evening. Arrival in Madrid on Wednesday $29^{\text {th }}$ February at 10 o'clock in the morning. ${ }^{87}$

Thanks to the recent construction of the Madrid-Alicante railway, officially inaugurated in May 1858, another means of transport appeared for the first time as a support to the performance of the sea cruise. The opening of this new land-based means of mobility, which placed the capital of the kingdom within closer reach of the Mediterranean, had an immediate effect on demand for maritime passenger traffic. ${ }^{88}$ It made it possible to approach a new market, opening new horizons for shipping companies. Several entities, in fact, began to divert their operations via the port of Alicante and they started to promote their services regularly in the newspapers of the capital. One of these was the general partnership Antonio López y Cía. This firm was officially incorporated in Madrid in January 1857 , although its origins can be found in the line of steamers that its founder and manager —Antonio López- established in Cuba in $1850 .{ }^{89}$ It soon became one of the main Spanish steamer companies, thanks largely to the close relationship that the manager was able to form with political powerbrokers. In 1862, the company was awarded the first of a long series of contracts for carrying mail to the West Indies, obtaining with this a corresponding state subsidy. Twenty years later, Antonio López was transformed into the public limited company Trasatlántica, in line with the 'spectacular' growth of its fleet. ${ }^{90}$

\footnotetext{
${ }^{87}$ El Clamor Público, February 19, 1860 (authors' translation).

${ }^{88}$ Julia A. Clancy-Smith, Mediterraneans. North Africa and Europe in an age of migration, c. 1800-1900, (Los Angeles: University of California, 2011), 92-93.

${ }^{89}$ Martín Rodrigo, Los marqueses de Comillas. Antonio y Claudio López 1817-1925, (Madrid: LID, 2006), 20-28. In the annual reports of the company, 1850 is considered as the year its activities commenced; see, for example, the special issue dedicated to its first centenary, Compañía Trasatlántica Española, Annual Report 1950, 9. See also Francisco de Cossio, La Compañía Trasatlántica. Cien años de vida sobre el mar, 1850-1950, (Madrid: Rico, 1950).

${ }^{90}$ Rodrigo, Los marqueses, 106-110. This author reminds us that 'a limited liability company, such as the new Trasatlántica, offered a series of advantages that were not available to partnerships, in particular the capacity to attract capital by means of bonds'.
} 
Returning to the issue in hand, Antonio López y Cía established its head office in Alicante, by virtue of the privileged position granted to it by the new railway line and its resulting link with the capital. Unlike other shipping companies, liner services offered by Antonio López steamers benefited from the direct support of the rail company, and was marketed daily in the Madrid press with the slogan 'in combination with the railways of Madrid'. Indeed, an agreement entered into with the railway company (MZA), allowed it to offer a 'high speed' service from the capital to Malaga, Cadiz, Barcelona, Marseilles and Paris, coordinating the timetables of its steamers with the operations of the train. ${ }^{91}$ All of this ensured a clear competitive advantage. Passengers could even purchase a combined ticket (train + steamer), either at the offices of the steamship company or at railway ticket offices. ${ }^{92}$ The idea for the expedition to Tetouan originated within the framework of this collaboration. To begin with, the joint organisation between the two transport companies was fruitful. Amidst a climate of enthusiasm generated by news from Africa, it appears that no fewer than 400 'notable' persons wished to take part in the event and to occupy the three classes of service offered by the two organisations. ${ }^{93}$ The total price of the trip varied according to the type of accommodation: $200 \mathrm{pts}$ (about $168 s$ ) to travel first class, $150 \mathrm{pts}$. (126 s) for second class, and 100 pts $(84 s)$ being the necessary sum to travel third class. ${ }^{94}$ The prices did not include meals on board the steamer, but did include overnight stays on board during the two night stopover in the bay of the Moroccan city. In view of these amounts, it is clear that only a small elite would have been able to attend the event. By way of example, in fact, the amount of 150 pts, equivalent to second class accommodation, represented slightly less than half of the gross annual salary received in Madrid, in 1860 , by a secretary of the city council or by a primary school teacher. ${ }^{95}$

Once more reflecting the challenges associated with organising these early steam-powered outings, the 'great pleasure travel' to Tetouan did not, finally, take place. The decision taken by the

\footnotetext{
${ }^{91}$ Diario Oficial de Avisos de Madrid, December 14, 1859.

${ }^{92}$ Rodrigo, Los marqueses, 28-29. On the relationship between the first Spanish railroad lines and tourism, see recent research by Rafael Barquín, 'El turismo y los primeros ferrocarriles españoles (1855-1900)', TST 24, no. 1 (2013): 110136.

${ }^{93}$ La Correspondencia de España, February 22, 1860.

94 The exchange rate is based on Aceña and Pons, 'Sistema monetario'.

${ }^{95}$ The estimate is based on official job announcements published by the Gaceta de Madrid (Spanish Official State Gazette), editions of the year 1860 .
} 
organisers, 'with the agreement' of Spanish military authorities, was attributed to 'difficulties' that had arisen unexpectedly in the 'boarding formalities and means of disembarkation'. ${ }^{96}$ All in all, the first efforts at promoting pleasure travel by Antonio López - Compañía Trasatlántica failed. Its real entry into the tourism market had to wait until the 1920 s, a result of the drastic decline in transoceanic emigration. But that is another story. ${ }^{97}$

\section{Conclusion}

Pleasure navigation began in Spain in the middle of the nineteenth century. An astonishing improvement in steam technology formed the foundation for this development. Shipping companies with an entrepreneurial vision took things from there, helping to establish regular lines, to expand passenger traffic, and to create a differentiated market that eventually drew a range of travellers. A cause and effect relationship between the first steamers and the appearance of recreational sea travel is beyond doubt. The case of Bilbao is perhaps the most indicative. The diffusion of steam in the Basque province began towards the end of the 1850s. In just three years, between 1858 and 1861, the registry of Bilbao recorded an increase of 11 functioning boats, rising from 4 to 15 steamers. ${ }^{98}$ Then, at the beginning of the 1860s, sources recount the commencement of the first summer expeditions.

As noted above, many of the first voyages did not take place for a host of reasons. In practice, with the exception of the cruise of the Ebro to the Balearic Islands in 1854, only day trips materialised. These outings occurred mainly at the island of Majorca, attracting large numbers of trippers on many occasions. During this early period, recreational sea travel in Spain almost always involved little more than a short trip to a nearby location, with no overnight stay, consisting of a planned visit to a place of interest or the witnessing of some specific event. Longer voyages took

\footnotetext{
${ }^{96}$ La Correspondencia de España, February 23, 1860.

${ }^{97}$ See Gaetano Cerchiello, 'La evolución del crucerismo en España. Desde sus orígenes hasta la actualidad (18482013)' (PhD. diss, University of Alicante, 2013), 138-158.

${ }^{98}$ Anuario estadístico de España, editions 1859-1861. On this process see José M. Valdaliso, Los navieros vascos y la marina mercante en España, 1860-1935. Una historia económica (Bilbao: Instituto Vasco de Administración Pública 1991).
} 
much more time to develop as a viable element of the market. In view of the lack of clientele willing to travel for pleasure over several days, steam companies chose to organise trips by taking advantage of some extraordinary event that might arouse greater interest. The most striking example was the cruise to Tetouan. The idea of associating a warlike event with recreational travel is merely a reflection of the difficulties organisers encountered in finding a minimum number of participants. Indeed, it was not until the end of 1869 that the first long-duration cruise took place in Spain. That year, the steamer Pelayo managed to leave Barcelona en route to one of the most transcendental events of the era: the inauguration of the Suez Canal. ${ }^{99}$

Until only a few decades ago, the cruise remained a privilege of the wealthy classes. Response to the first initiatives in Spain was linked to whether the journey was to be long or short. Although both types of trip were taken for pleasure, the two products were very different, and even more so from the point of view of demand. When the duration of travel was increased, it became a much more selective practice, a true luxury within the exclusive reach of very few, available only to those who had a high income and sufficient time. These two factors, however, did not have such a decisive impact on day trips. If, in addition to all of this, we add the aforementioned lack of a travelling culture among Spanish elites, and the fact that the first steamers were not equipped to guarantee the enjoyment of a long sea crossing, we obtain a more defined picture of the differentiating features of Spanish cruising in this first phase.

${ }^{99}$ Cerchiello, 'Turismo de eventos', 95-115. 